\title{
ORGANIZATIONAL RESTRUCTURING AND OWNERSHIP TRANSFORMATION IN POLAND'S INLAND SHIPPING COMPANIES AFTER 1990
}

\author{
ZBIGNIEW TAYLOR and ARIEL CIECHANSKI \\ Institute of Geography and Spatial Organization, Polish Academy of Sciences, \\ Twarda 51/55, 00-818 Warsaw, Poland \\ E-mails: z.taylor@twarda.pan.pl; ariel@twarda.pan.pl
}

\begin{abstract}
This article seeks to reconstruct organizational and ownership changes affecting Polish enterprises in inland shipping since 1990. On the basis of data from various sources (above all the Polish Registry of Ships and Bulletins of Public Information), it was possible to determine the degree of advancement of the transformation processes affecting shipping companies, these first and foremost denoting privatization and partial communalization, as well as organizational changes. A particular kind of dichotomy is observable in that, while most newly-arising entities are small private shipping enterprises created as former state-owned enterprises have been divided up and their vessels sold to new owners, the systemic transformation plus Poland's EU accession have also given rise to the conditions underpinning the emergence of Europe's largest shipowners (the Odratrans group), the latter dealing with carriage by barge along inland waterways, including beyond Poland.
\end{abstract}

Key words: systemic transformation, inland shipping, privatization, communalization, geography of enterprises, Poland

\section{INTRODUCTION}

According to Europe develops inland shipping (2001), the European inland shipping fleet embraces over 10,000 vessels altogether, of which more than half (5600) are registered in The Netherlands. It is estimated that about 80-90 per cent of these belong to family firms, associated in eight shipping unions. The German share, the second largest, involves one quarter of the fleet sailing on the Rhine. In third place is Belgium with 1350 vessels, 95 per cent owned by family firms quite frequently possessing just one unit. Overall, about 90 per cent of the inland fleet within the EU belongs to individual owners mainly using one vessel only. The number of large shipping companies in Europe is estimated at 25 (Lepek 2009). What is then the place and situation in the European context of Poland, with her fleet several hundred vessels strong?

This paper represents a continuation of the authors' previous interest in the processes of privatization and deregulation in Polish rail, road and urban transport (Taylor and Ciechanski 2006, 2008, 2010a). It seeks to reconstruct the process of organizational and ownership transformation affecting inland shipping companies in Poland post-1990. On the basis of vessels registered in the Polish Registry of Ships, the authors compiled a list of carriers in inland shipping 
embracing almost 110 firms overall. Thereafter, the list was reduced in length through the exclusion from further analysis of firms having vessels not used in carriage activity, e.g. those moored at wharfs (and serving as cafés, restaurants or hotels), firms not engaging in carriage, or using vessels mainly for the transport of their own products, or using them in the discharge of duties by state and local government administrations. Rope ferries and icebreakers have not been included in the analysis either. The remaining set was then divided by type of service provided into: (1) inland passenger scheduled shipping; (2) inland passenger non-scheduled shipping; and (3) inland freight shipping. The spatial distribution of these is here shown and analysed, following a presentation of the legal background, plus a history and description of inland shipping companies.

\section{LEGAL FOUNDATIONS OF POLAND'S INLAND SHIPPING}

Prior to 20 December 2000, inland shipping in Poland was engaged in on the basis of the Act on Shipping and Floating on Inland Water Routes (Ustawa..., 1950) which has been amended several times. That Act defines vessels (including Polish ones) and conditions for the movement of foreign units along Polish waterways, by and large in line with international agreements. Only units possessing certification of shipping capability may be used, and firms should possess concessions for earning and the professional carriage of people and commodities. The conditions for concessions have been defined scrupulously, but it is notable that state companies (being in an absolute majority) are exempted. The Act on Economic Activity of 1988 (Ustawa..., 1988) which liberalised many previous economic regulations also dispensed with the necessity of concessions.

At the end of 2000, a new Act on Inland Shipping (Ustawa..., 2001a) was introduced, regulating matters of inland navigation on navigable waterways on the basis of the Water Law Act. In accordance with the former
Act (Ustawa..., 2001a), a Polish ship may be in the ownership of the Treasury, a firm registered in Poland, or citizens living in the country. The Minister and directors of transport are responsible for the administration of inland shipping. Not only Polish, but also foreign vessels can sail, providing there are international agreements between Poland or the EU and the state of a ship's registration. Where such an agreement has not been concluded, a Minister (in the case of navigation between Polish ports, or between Polish and foreign ports) or the director of an inland navigation office (all other cases) must assure a permit for sailing. These rules do not apply to sporting or recreational vessels irrespective of national registration.

Profitable freight carriage in national or international transport as an operator activity can be engaged in by an entrepreneur in possession of a professional capability certificate, or employing at least one person with such a certificate. Carrier capability is not required of a business person engaging in shipping for his/her own use, using vessels with a capacity of up to 200 tonnes, using ferries, and/or not using officially-designated navigable waterways. Professional capability is acknowledged to characterise graduates of a higher school in the transport field or school-leavers from a secondary school specialising in inland shipping, as well as the own qualifications of the captain of a vessel above 200 tonnes, who has received training, or has been involved in practice in carriage activity for at least two years, or has been employed in inland shipping elsewhere. Polish vessels are required to be listed in the inland shipping registry.

The Water Law Act of 1974 (Ustawa..., 1974) applies to inland shipping to only a slight extent. At present the status of waterways is as set out in the new Water Law Act of 2001 (Ustawa..., 2001b): all waters (with the exception of territorial seas and expanses of marine water extending inland) are treated as inland waters. Those being in the ownership of the Treasury are public waters, including inland sea waters plus the Gulf of Gdansk, running surface inland waters 
and underground waters. While navigation is treated by law as a special usage of water resources, no special permits are requested. The Water Law Act (Ustawa..., 2001b) also lays down fees for the usage of waterways and their facilities (for example locks) that are under the ownership of the Treasury.

It was in 2000 that the market in respect of inland shipping was in practice deregulated, in that there was full liberalisation as regards the concluding of agreements and the negotiation of prices for the chartering of vessels. Where access to the profession of carrier in EU countries is concerned, two rules remain valid - the confirmation of professional qualifications and the mutual recognition of documents confirming these (Paprocki and Pieregud 2004).

From 1 May 2004, Polish shipowners have been in a position to offer cabotage carriage in EU countries without limitations. Prior to that, certain permits, certifications and qualifications were necessary, these being as far-reaching as, for example, knowledge of local language by a vessel's captainlike German in Germany. The liberalisation of the market had the effect that, in 2004, the carriage supplied by Polish shipowners was three times the level observed in 2003 (and at five times the level by 2005). In that year international connections involving Polish shipowners concerned some 5.1 million tonnes in freight, 40 per cent more than in 2004 (Bujak 2004). There was a dominance here of cabotage in international links, especially between the German ports.

\section{OWNERSHIP TRANSFORMATION OF FORMERLY STATE-OWNED FIRMS}

Pre-1990 there were seven state-owned companies in inland shipping. The founder of four of these (Bydgoszcz Shipping, Gdańsk Shipping ${ }^{1}$, Szczecin Shipping, and

${ }^{1}$ Gdańsk Shipping has been and remains only partly an inland shipping company, being principally the largest coastal shipping company operating out of the seaports of Gdańsk, Ustka and Kolobrzeg, as well as on Zalew Wiślany (the Vistula Lagoon) and in the Gulf of Puck.
Odra Shipping) was the Minister responsible for matters of transport. In the case of Mazurian Shipping the role in question was played by the provincial governor in Suwałki, while in the case of Cracow Shipping it was the governor in Cracow, and for Warsaw Shipping the President of the capital city. The joint-stock company called Navatrans (with representatives in Berlin, Duisburg and The Hague) has been given responsibility of protecting businesses against the Inland Shipping Consortium of Germany. Then, there were the eight inland ports on the River Odra, two on the Warta, three on the River Notec and the Bydgoszcz Canal, and four on the Vistula and Nogat. All of these were subordinated to shipping companies. The situation of small throughput facilities was similar (Kwiatkowska 1992).

The situation changed with the systemic transformation. At the beginning of 1991, the state enterprise called Mazurian Shipping was split into three smaller, but also state-owned, firms (Augustów Shipping operating tourist tours in the Suwalki-Augustów Lakeland, Ostróda-Elbląg Shipping proving tourist tours on the Elbląg Canal, and Mazurian Shipping operating on the Great Mazurian Lakes). The two smallest firms-Warsaw Shipping and Cracow Shipping-were closed down in 1991. The river ports of Warsaw Shipping have been transformed into a public utility, and its fleet sold to a private (no longer existing) company (Kwiatkowska 1992). In 1991, Swinoujście Shipping was separated from Szczecin Shipping and formed a budgetary entity responsible for ferry carriage in the city of Swinoujście (Milkowski 1997).

In 1992, Ostróda-Elbląg Shipping was communalized and included as an element of urban transport, as it remains today (Taylor and Ciechański 2010a; <www.zegluga. com.pl>). No action in relation to Gdańsk Shipping and Szczecin Shipping was then taken (Rydzkowski and Rolbiecki 1993).

Poland's coastal shipping is almost exclusively concerned with the carrying of passengers, first and foremost around the home ports <www.zegluga.pl > 
A year later, the closed-down firm Cracow Shipping was sold to a private entrepreneur, and in mid-1990s Gdańsk Shipping (quite a large firm) was purchased by two other people. However, the traditional name of the firm has been retained for the newly-created limited-liability compa ny. In 1995, Bydgoszcz Shipping was transformed into a single-person Treasury company (Milkowski 1997). In turn, in 1997, Augustów Shipping was leased and later on privatized, and two years later Mazurian Shipping was leased as a workers' company, in which legal form it remains today. The present-day situation of former state firms in inland shipping is given in Table 1. governments in the cities of Wroclaw, Poznan and Szczecin, and to Silesian companies. Yet in 1948, the company was closed down, and a new state firm called State Odra Shipping with its seat in Wroclaw was launched, mainly on a basis of property belonging to the Treasury. This was then a state enterprise until 1992, when it was transformed into a joint-stock company belonging wholly to the Treasury, the name being changed to Odratrans (Odratrans..., 2005). Shares were then assigned to national investment funds, workers, foreign and strategic investors, as well as the Treasury. Indeed in 1993, the processes of transformation were mostly advanced in the case of Odratrans, and the

Table 1. The legal forms of former state-owned firms in inland shipping as of 2010

\begin{tabular}{|c|c|c|c|}
\hline $\begin{array}{l}\text { Present name } \\
\text { of shipping firm }\end{array}$ & Legal form & $\begin{array}{l}\text { Year } \\
\text { of change }\end{array}$ & Comments \\
\hline Odratrans SA & joint-stock company & 1992 & $\begin{array}{l}\text { former Żegluga na Odrze } \\
\text { [Odra Shipping] }\end{array}$ \\
\hline $\begin{array}{l}\text { Żegluga Bydgoska SA } \\
\text { [Bydgoszcz Shipping] }\end{array}$ & joint-stock company & 1995 & consolidated with Odratrans \\
\hline $\begin{array}{l}\text { Żegluga Szczecińska sp. z o. o. } \\
\text { [Szczecin Shipping Limited] }\end{array}$ & $\begin{array}{l}\text { single-person Treasury } \\
\text { company }\end{array}$ & 2007 & rejection of communalization \\
\hline $\begin{array}{l}\text { Żegluga Świnoujska } \\
\text { [Świnoujście Shipping] }\end{array}$ & $\begin{array}{l}\text { budgetary entity of city } \\
\text { of Swinoujście }\end{array}$ & 1991 & $\begin{array}{l}\text { singled out from Szczecin } \\
\text { Shipping }\end{array}$ \\
\hline $\begin{array}{l}\text { Żegluga Mazurskà sp. z o. o. } \\
\text { [Mázurian Shipping Limited] }\end{array}$ & workers' company & 1999 & $\begin{array}{l}\text { in } 1991 \text { separated from state } \\
\text { company under similar name } \\
\text { (Mazurian Shipping) }\end{array}$ \\
\hline $\begin{array}{l}\text { Żegluga Augustowska sp. } \\
\text { z o. o. [Augustów Shipping } \\
\text { Limited] }\end{array}$ & $\begin{array}{l}\text { limited-liability company, } \\
\text { in private ownership }\end{array}$ & 1997 & $\begin{array}{l}\text { in } 1991 \text { separated from state } \\
\text { company Mazurian Shipping, } \\
\text { then in } 1997 \text { privatized }\end{array}$ \\
\hline $\begin{array}{l}\text { Żegluga Ostródzko-Elbląska } \\
\text { [Ostródá-Elblạg Shipping] }\end{array}$ & $\begin{array}{l}\text { branch of Urban Transport } \\
\text { in Ostróda, budgetary entity }\end{array}$ & 1992 & $\begin{array}{l}\text { separated from the state } \\
\text { company Mazurian Shipping }\end{array}$ \\
\hline
\end{tabular}

Authors' own work based on: Kwiatkowska (1992), Milkowski (1997)

\section{ESTABLISHMENT OF THE ODRATRANS GROUP}

Odra Shipping (Źegluga na Odrze), the largest of all the firms in inland shipping, has a particularly long and interesting history. It was founded in 1946 as Polish Odra Shipping Limited, with shares belonging to the Ministry of Transport, Polish Water Routes, local mode of privatization had been chosen (the so-called 'capital way'). As early as in 1991, an attempt to privatize Bydgoszcz Shipping in a similar way had been analysed, though the attempt had to be abandoned owing to financial problems arising at unprofitable river ports belonging to the carrier (Rydzkowski and Rolbiecki 1993), these only in fact being sold quite recently (Diagnoza..., no date). 
Post 1995, Odratrans was gradually brought more and more into investment funds, these selling it to two limited-liability companies in 2003 (Sibilski 2003). Some years later the two companies purchased almost all of the shares, as well as a majority of the shares in Bydgoszcz Shipping-hitherto its largest competitor. The initial idea was for some of the barges to be leased to their crews, but soon all had been leased (Wojewódzka-Król et al. 2000). So, under the new model of management the crew was responsible for operations, i.e. the running and technical sides, while the shipowners were involved in the business sphere. By and large, the results have been very positive: voyage times have been shortened, costs of vessels' exploitation and maintenance lowered, and the efficiency of ships increased.

In 2007, Odratrans purchased 72 per cent of the shares in Deutsche Binnenreederei, a joint-stock company from Berlin. In 2009, Bydgoszcz Shipping was consolidated with Odratrans, whose owners in 2010 were one of the Polish national investment funds (75 per cent of the shares) and a Luxembourg investment fund (the remaining 25 per cent).

In 2009 , there were 16 companies belonging to the Odratrans capital group (Fig. 1). By comparison, in 2005 there had been just 10. In Germany, there is Deutsche Binnenreederei, a dependent company providing mass carriage of freight on inland waterways. The latter company is the only shareholder in Odra Rhein Lloyd GmbH-a business representative in Germany, while the second dependent firm Elbe Rijn Lloyd bv (51\% of shares) is registered in The Netherlands and provides carriage between the Elbe and the Rhine. The remaining 13 companies are registered in Poland and can be divided into firms involved in inland shipping (such as Odratrans, Bydgoszcz Shipping and Odra Lloyd), other transport activities (rail and road transport ${ }^{2}$, logistics, inland ports, the seaport of Świnoujście), and non-transport

2 Including Rentrans Cargo Limited in which the foreign minority shareholder is a firm registered in Slovakia-this attesting to the international nature of the group. activities (shipyards, repair work and real estate).

Following the takeover of Deutsche Binnenreederei, Odratrans became the largest inland shipowning group in Europe. Via a Polish-German merger, the fleet has come to exceed 900 vessels, of total tonnage 450,000 tonnes, including 260 motor barges and pushers, and 550 barges without their own propulsion. This fleet is used mainly in the area between the Rhine and the Odra, jointly with the seaport services in Hamburg, Bremen and Szczecin (Lepek 2009).

\section{CARRIERS}

In the above manner, the two largest companies Odratrans and Bydgoszcz Shipping have been privatized within one capital group. The other formerly state shipowning firms have been communalized or closed down. On the basis of the latter, almost 200 small private companies in inland shipping (Paprocki and Pieregud 2004) have been created ${ }^{3}$. These are spread all over the country (Fig. 2).

For the purposes of this article, the carriers have been divided into: (1) inland passenger scheduled shipping; (2) inland passenger non-scheduled shipping; and (3) inland freight shipping.

\section{CARRIERS IN REGULAR PASSENGER SHIPPING}

Among the 38 firms presented in Table 2 just several were active prior to 1989. As mentioned, Mazurian Shipping, Augustów Shipping and a budgetary unit within Urban Transport-called Ostróda-Elbląg Shipping-formerly constituted one state company called Mazurian Shipping. Świnoujście Shipping has been singled out of Szczecin Shipping. All other companies have been private initiatives from the very beginning. Usually they have one or several vessels at most (Fig. 3).

3 For comparison: in 1992 there were just 6 private shipping firms, in 1993-56, in 1998-c. 150 (Bạkowski 1995; Milkowski 1997; Paprocki and Pieregud 2004). 


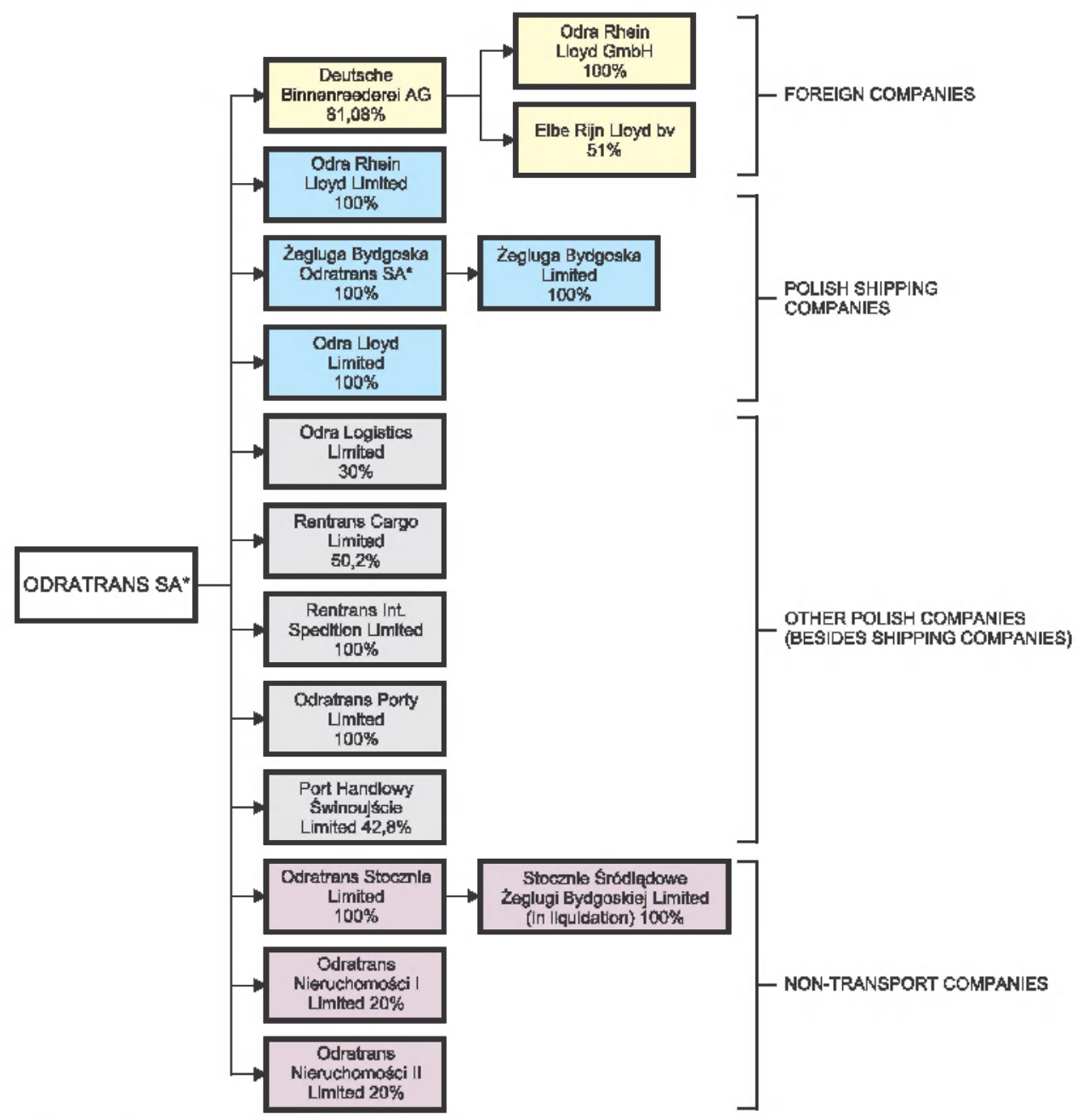

* SA- joint-stock company

Figure 1. Structure of the Odratrans SA capital group in 2009

Source: <www.odratrans.com.pl>, altered.

Several geographical areas of activity of private shipowners can be distinguished. On the River Odra practically all navigation is concentrated around the city of Wroclaw. Three carriers (all mentioned in Table 2) practically operate within the administrative borders of the city. The second segment of the Odra waterway used in scheduled passenger traffic embraces the environs of Szczecin and Świnoujście. These cities are connected by a hydrofoil route operăted by the Wodoloty company. Moreover, Maritime Services provides regular navigation in Szczecin seaport and on nearby Lake Dąbie. Świnoujście Shipping included among transport services in turn offers ferry crossings for passengers and cars in the city centre, as well as to/from Karsibór island.

Rather more developed is the regular passenger navigation on the River Vistula. 


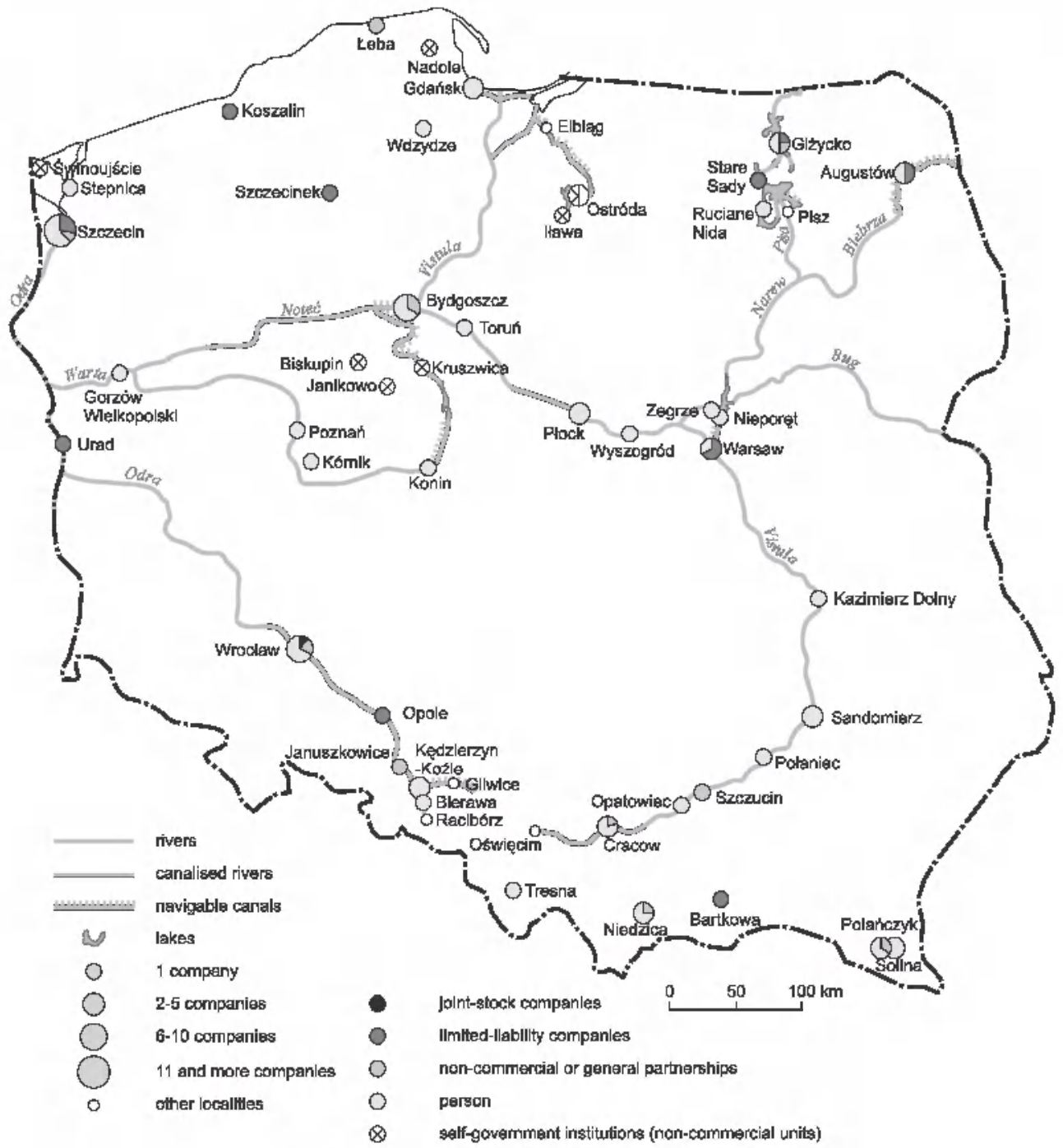

Fignre 2. Location of inland shipping carriers in 2009

Authors owin work based on <www.prs.pl> and carriers' welpages.

Two carriers provide regular shipping within the city of Cracow. Ster Partnership operates to nearby Tyniec Abbey and within the Cracow city limits. Similar services are provided by the firm belonging to Marek Morawiec. A purely private firm also operates around Kazimierz Dolny, which is a superior tourist attraction. Capital Shipping provides onehour journeys on the Vistula, as well as wa- ter tramway services in Warsaw city. Emmet Cruise operates along a regular shipping route between Warsaw and Serock, while another carrier provides scheduled passenger transport on the Zegrze Reservoir. In Torun, excursions along the Vistula are offered by Czeslaw Blocki Shipping Services, a firm based within the Warsaw conurbation. On behalf of the Bydgoszcz authorities, 


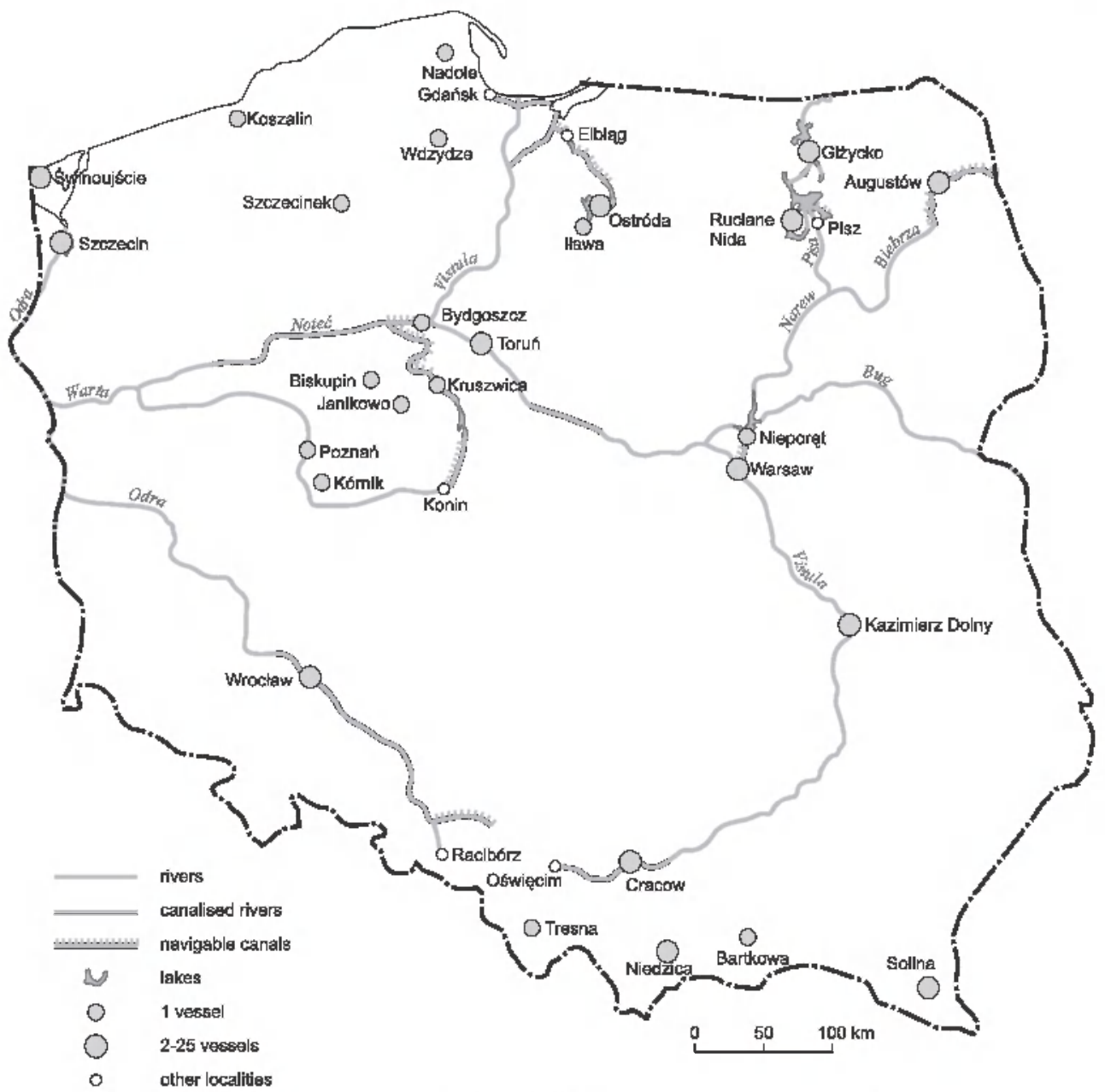

Figure 3. Locations of the inland shipping scheduled passenger fleet

Authors' own work based on <www.prs.pl> and carriers' webpages.

Bydgoszcz Shipping (now belonging to the Odratrans group) operates a water tramway in the city centre.

A separate group of carriers function on bodies of water-most of them within the Mazurian Lakeland. A majority of these carriers originated from the formerly stateowned Mazurian Shipping company. Besides them, carriage on Lake Jeziorak is engaged in by the Ilawa Centre for Sport, Tourism and Leisure, and Faryj's Yachting Port provides a regular shipping line from Ruciane Nida to Mikolajki in the Great Mazurian Lakes.
An offer of scheduled shipping is supplemented by PPH Armator operating on Lake Wigry (near Suwalki).

The second concentrátion of regulari pássenger navigation involves artificial lakes in southern Poland, above all the Solina Reservoir with its three different carriers. Two other carriers operate on the Czorsztyn Reservoir (Table 2).

Just single carriers operăte on other bàsins. The first group comprises local governments and firms dependent on them (on lakes such as Jamno, Trzesiecko, Pakoskie, 
Table 2. Passenger carriers in scheduled shipping

\begin{tabular}{|c|c|}
\hline Shipowner's name & Services \\
\hline Żegluga Świnoujska [Świnoujście Shipping] & ferry shipping in the city of Swinoujscie \\
\hline Wodoloty sp. z o.o. [Hydrofoil Limited] & hydrofoil tourist trips on the Szczecin-Swinoujscie route \\
\hline Uslugi morskie [Maritime Services] & $\begin{array}{l}\text { tourist trips on Lake Dąbie and around the port } \\
\text { of Szczecin }\end{array}$ \\
\hline $\begin{array}{l}\text { Zegluga Pasażerska Flis Adam Rysiew [Flis Adam } \\
\text { Rysiew Passenger Shipping] }\end{array}$ & tourist trips along the Odra near the city of Wroclaw \\
\hline $\begin{array}{l}\text { Żegluga Pasażerska Hordejuk Rafat [Hordejuk Rafal } \\
\text { Passenger Shipping] }\end{array}$ & tourist trips along the Odra near the city of Wroclaw \\
\hline $\begin{array}{l}\text { Retman Żegluga Pasażerska [Retman Passenger } \\
\text { Shipping] }\end{array}$ & tourist tours along the Odra within the city of Wroclaw \\
\hline Odratrans SA (Bydgoszcz Shipping) & water tramway in the city of Bydgoszcz \\
\hline Prom Wisloujście UŻiE [Wisloujście Ferry] & ferry shipping within the city of Gdańsk city \\
\hline $\begin{array}{l}\text { Usługi Żeglugowe Trans-Wod Czeslaw Blocki [Czeslaw } \\
\text { Blocki Trans-Wod Shipping Services] }\end{array}$ & tourist trips along the Vistula within the city of Torun \\
\hline Stanislaw Jurkowski & tourist trips on the Zegrze Reservoir \\
\hline Emmet Cruise-Jan Popończyk & tourist trips on the Warsaw-Serock route \\
\hline Żegluga Stoleczna sp. z o. o. [Capital Shipping Limited] & tourist trips along the Vistula near Warsaw \\
\hline $\begin{array}{l}\text { Zegluga Pasażerska, Henryk Skoczek [Henryk Skoczek, } \\
\text { Passenger Shipping] }\end{array}$ & tourist trips along the Vistula near Kazimierz Dolny \\
\hline Marek Morawiec & tourist trips along the Vistula near Cracow \\
\hline $\begin{array}{l}\text { Ster s.c. Ewa Bigosz-Jerzy Wiśniewski [Ewa Bigosz- } \\
\text { Jerzy Wiśniewski, Ster Partnership] }\end{array}$ & tourist trips along the Vistula within the city of Cracow \\
\hline $\begin{array}{l}\text { Miejski Zakład Komunikacji sp. z o.o. w Koszalinie } \\
\text { [Urban Transport Limited in Koszalin] }\end{array}$ & tourist trips on Lake Jamno \\
\hline Urząd Miasta w Gniewinie [City Office in Gniewino] & tourist trips on Lake Żarnowiec \\
\hline Inter Nos sp. z o.o. [Inter Nos Limited] & ferry to Soltysia Island on Lake Lubie \\
\hline $\begin{array}{l}\text { Żegluga Mazurska sp. z o.o. [Mazurian Shipping } \\
\text { Limited] }\end{array}$ & tourist trips within the Mazurian Lakeland \\
\hline $\begin{array}{l}\text { Zakład Komunikacji Miejskiej w Ostródzie [Urban } \\
\text { Transport Unit in Ostróda] }\end{array}$ & tourist trips along the Elblagg Canal \\
\hline $\begin{array}{l}\text { Ilawskie Centrum Sportu, Turystyki i Rekreacji [Ilawa } \\
\text { Centre for Sport, Tourism and Leisure] }\end{array}$ & tourist trips on Lake Jeziorak \\
\hline Port Jachtowy u Faryja [Faryj's Yachting Port] & tourist trips along the Ruciane Nida-Mikolajki route \\
\hline $\begin{array}{l}\text { Przedsiębiorstwo Żegluga Augustowska sp. z o. o. } \\
\text { [Augustów Shipping Company Limited] }\end{array}$ & tourist trips within the Augustów Lakeland \\
\hline PPH Armator & tourist trips on Lake Wigry \\
\hline $\begin{array}{l}\text { Komunikacja Miejska sp. z o.o. [Urban Transport } \\
\text { Limited] }\end{array}$ & the water tramway on Lake Trzesiecko \\
\hline $\begin{array}{l}\text { Przystań Wodna Grzegorz Turzyński [Grzegorz Turzyński } \\
\text { Marina] }\end{array}$ & tourist trips on Lake Wdzydze \\
\hline Michat Walczak & tourist trips on Lake Niedzięgiel \\
\hline $\begin{array}{l}\text { Państwowe Muzeum Archeologiczne-Oddzial } \\
\text { w Biskupinie [State Archaeological Museum-Biskupin } \\
\text { Branch] }\end{array}$ & tourist trips on Lake Biskupin \\
\hline Miasto i gmina Janikowo [Town and Gmina in Janikowo] & tourist trips on Lake Pakoskie \\
\hline Urząd Miasta w Kruszwicy [Town Office in Kruszwica] & tourist trips on Lake Goplo \\
\hline
\end{tabular}




\begin{tabular}{|c|c|}
\hline Shipowner's name & Services \\
\hline PHT Bas & tourist trips on Lake Kórnik \\
\hline Robert Dusza & tourist trips on the Żywieckie Reservoir \\
\hline $\begin{array}{l}\text { Rest sp. z o.o. DW. Stalownik [Rest Limited, Stalownik } \\
\text { House] }\end{array}$ & tourist trips on the Rożnów Reservoir \\
\hline $\begin{array}{l}\text { Przedsiębiorstwo Kamieniarskie Kazimierz Wolski } \\
\text { [Kazimierz Wolski Masonry Company] }\end{array}$ & tourist trips on the Czorsztyn Reservoir \\
\hline $\begin{array}{l}\text { Żegluga i Turystyka s.c. Lucyna Wolska, Tomasz Jandura } \\
\text { [Lucyna Wolska-Tomasz Jandura, Navigation and } \\
\text { Tourism Partnership] }\end{array}$ & tourist trips on the Czorsztyn Reservoir \\
\hline Biala Flota Jerzy Czerski [Jerzy Czerski Passenger Fleet] & tourist trips on the Solina Reservoir \\
\hline Tramp s.c. [Tramp Partnership] & tourist trips on the Solina Reservoir \\
\hline $\begin{array}{l}\text { Wypożyczalnia Sprzętu Wodnego [Water Equipment } \\
\text { Rental Company] }\end{array}$ & tourist trips on the Solina Reservoir \\
\hline
\end{tabular}

Authors' own work based on Polski Rejestr Statków and carriers' webpages.

Zarnowiec and Goplo). On the first two of these lakes, sailings are engaged in within urban transport companies. The second group is formed from private carriers on natural or artificial lakes such as Niedzięgiel, Kórnik, Wdzydze, Rożnów and Żywiec, spread all over the country. There is also one private ferry to the camping site on Soltysia Island in Lake Lubie (Fig. 3).

\section{CARRIERS IN IRREGULAR PASSENGER SHIPPING}

There are many fewer (16) passenger carriers in irregular shipping, all being owned by private capital (for a full list, see Taylor and Ciechański 2010b). Four of them offer charter tours along the Vistula around the historic town of Sandomierz (two firms), the city of Cracow (one firm) and the city of Plock (also one firm). Two other companies operate on the Solina and Czorsztyn Reservoirs. A distinguished group of six carricrs operates in the region of the Great Mazurian Lakes. Other carriers offer their services on the Konin-Kruszwica waterway in central Poland, on Lake Lébsko on the central Baltic seacoast and on Szczecin Bay. The spatial distribution of carriers in irregular passenger shipping is depicted in Fig. 4.

What is common to scheduled and nonscheduled passenger inland shipping in $\mathrm{Po}$ land is the absolute dominance of tourist traffic, with everything else being merely an addition to this basic type of activity. One of the consequences is a seasonal (mainly summer) rather than a year-round sort of activity, while the second is a dominance of short-distance navigation. The development of passenger shipping is doubtless mainly connected with the enormous growth in tourist traffic observed in the post-communist period (notably the discovery of the country by Western Europeans), with Poland's accession to the EU, and-last but not least-with the liberalization of the legal system as a condition underpinning the growth of private initiative.

\section{CARRIERS IN FREIGHT SHIPPING}

The Polish network of inland waterways is enormously heterogeneous in regard to navigation parameters and types of route (rivers, canalised rivers and navigable canals). In addition, conditions for navigation are limited by natural phenomena, such as water-level fluctuations or ice-cover periods. Anthropological conditions are not very favourable either, for the largest rivers and their tributaries are not regulated, for historical, economic and-nowadays-ecological reasons. Similarly, the number of inland ports is too small (Czarmanska et al. 2003; Kulczyk and Winter 2003; Paprocki and Pieregud 2004). 


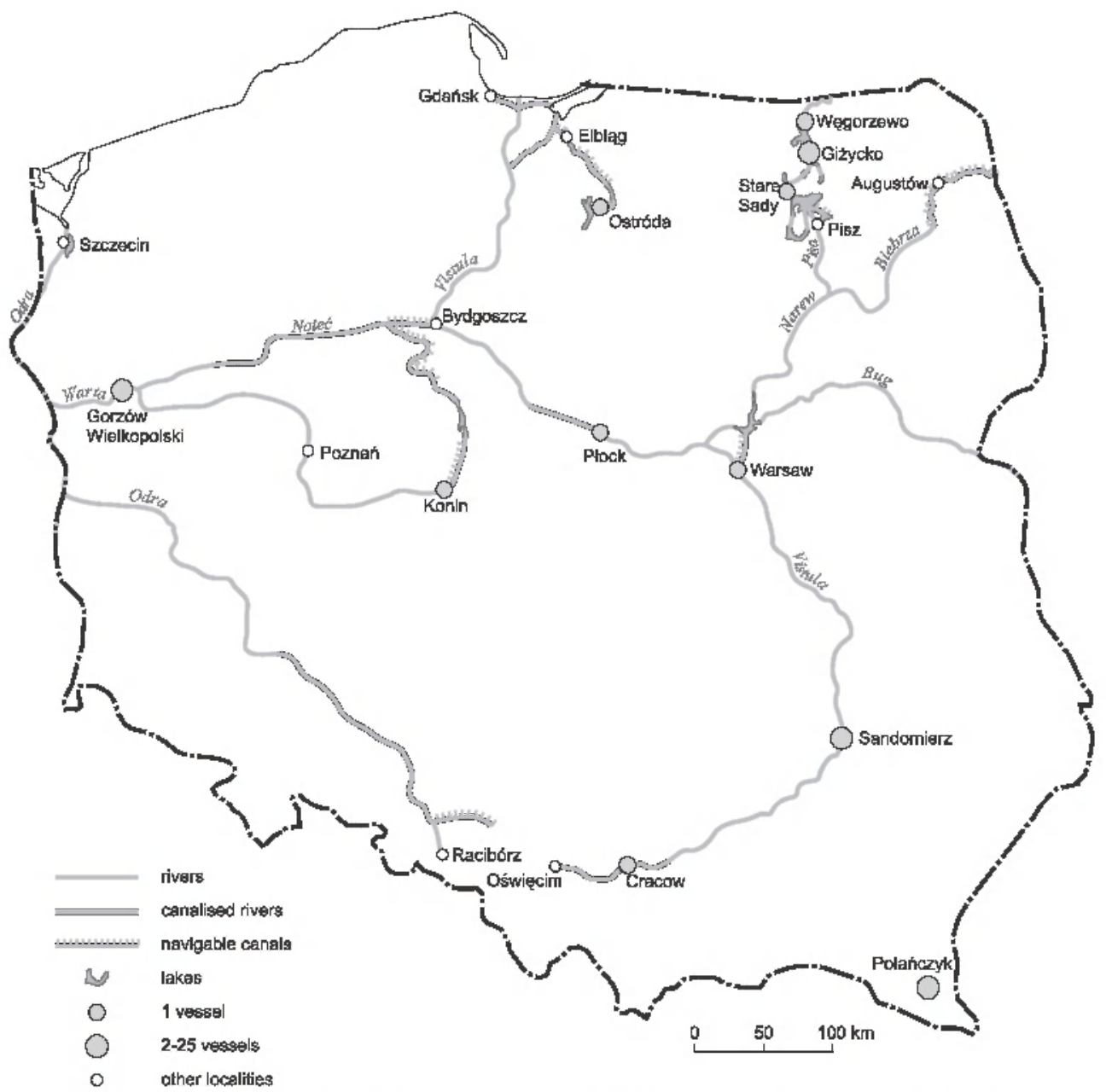

Figure 4. Locations of the inland shipping non-scheduled (irregular) passenger fleet Authors' own work based on <www.prs.pl> and carriers' webpages.

The limitations to inland shipping infrastructure condition what is a marginal role on the Polish transport market. The share in freight carriage fluctuated by an estimated 0.7 per cent in the years 1995-2001 (Paprocki and Pieregud 2004).

The inland carriers in freight shipping can be divided into three sections. The first consists of Odratrans (291 vessels in 2009) and dependent companies (c. 100), possessing the largest Polish fleet of about 400 units altogether. The second group consists of car- riers having at least two vessels at their disposal, while the third comprises small firms possessing just one vessel. The distribution of the fleet across the country is as presented in Fig. 5.

Altogether, there are 24 companies possessing at least two vessels (Table 3 ). Three of these (Comal Company, Ryszard Marczewski and the Water Services Company of M. Jurkowski) only have barges lacking propulsion-in the first case tank barges for the transport of liquid fuels. The majority 


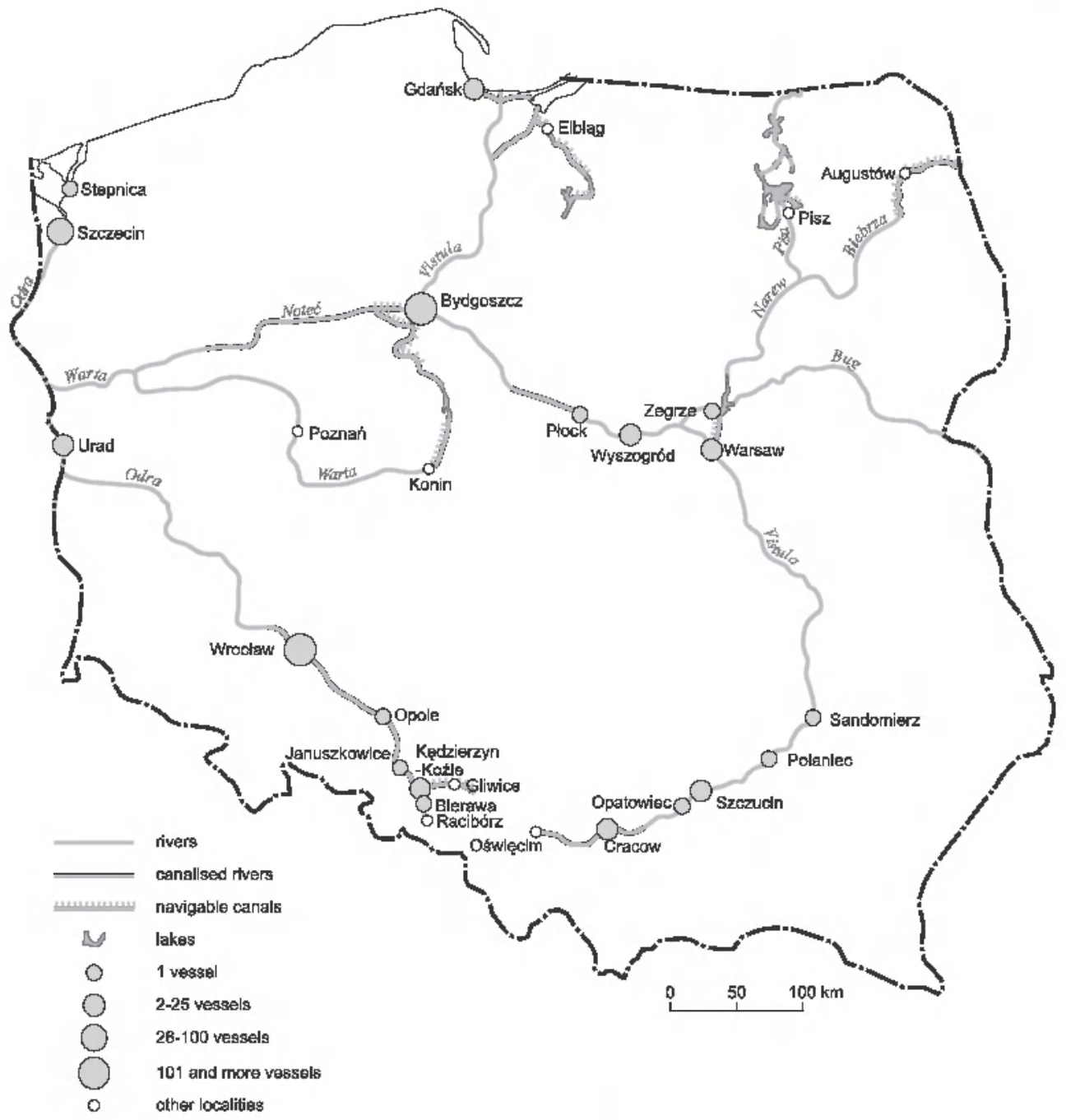

Figure 5. Locations of the inland shipping cargo fleet

Authors' own work based on <www.prs.pl $>$ and carriers' webpages.

of carriers possess two pushers and several barges. Navigar and Fabico have five or six pushers at their disposal. The AGT Shipping Company of Szczecin, besides a pusher, owns four motor barges. Smaller carriers own one pusher plus one barge. Where the spatial distribution is concerned, the majority of carriers are found to be registered in Szczecin, including vessels with their own propulsion. The next inland ports of importance are Wroclaw and Gdanisk, each having three operators registered, including one common to Szczecin and Wroclaw. Besides, in the city of Cracow there are vessels belonging to two registered carriers. Wyszogród, Stepnica, Uråd, KędzierzynKoźle, Szczucin, Polaniec, Sandomierz, Zegrze and Bydgoszcz only have stationed vessels of single owners.

A rather large group of carriers have just one merchant vessel (full list in Taylor and Ciechański 2010b). Only vessels for 
Table 3. Major carriers in inland freight shipping, owning more than one vessel (besides companies of the Odratrans group)

\begin{tabular}{|c|c|c|}
\hline Shipowner's name & Ports & Vessels \\
\hline $\begin{array}{l}\text { Żegluga Wyszogrodzka kpt. Żeglugi Jerzy } \\
\text { Pielacinski [Wyszogród Shipping] }\end{array}$ & Wyszogröd & 2 pushers, 5 pushed barges \\
\hline Deni-Janina Denisz & Szczecin, Wroclaw & 2 pushers, 3 pushed barges \\
\hline $\begin{array}{l}\text { AGTj Przedsiębiorstwo Żeglugowe sp. z o. o. } \\
\text { [AGTi Shipping Company Limited] }\end{array}$ & Szczecin & 1 pusher, 4 motor barges \\
\hline Fabico Zbigniew Fabiańczyk & Szczecin & 6 pushers, 1 motor barge, 11 pushed barges \\
\hline Frachtpol s.c. [Frachtpol Partnership] & Szczecin & 2 motor barges \\
\hline Konstal Pawel Pietruszczak & Szczecin & 2 motor barges \\
\hline $\begin{array}{l}\text { Muflon } 09 \text { Śródlądowy Transport Wodny } \\
\text { [Muflon } 09 \text { Inland Water Transport] }\end{array}$ & Szczecin, Stepnica & 2 pushers \\
\hline $\begin{array}{l}\text { Żegluga Szczecińska sp. z o. o. [Szczecin } \\
\text { Shipping Limited] }\end{array}$ & Szczecin & 2 pushers, 2 barges \\
\hline $\begin{array}{l}\text { Port Żegluga Szczecinska sp. z o. o. [Szczecin } \\
\text { Shipping Port Limited] }\end{array}$ & Szczecin & 1 pusher, 8 pushed barges \\
\hline $\begin{array}{l}\text { Projekt Żegluga sp. z o. o. [Shipping Project } \\
\text { Limited] }\end{array}$ & Szczecin & 2 pushers, 4 barges \\
\hline Navigar Deneko-Garbień s.j. & Szczecin & 5 pushers, 6 pushed barges \\
\hline P \& D sp. z o. o. [P \& D Limited] & Urad & 1 pusher, 1 pushed barge \\
\hline Transbode s.j. Z. Bogumil., Z. Deniusz & Wroclaw & 1 pusher, 1 motor barge, 2 pushed barges \\
\hline $\begin{array}{l}\text { Navatrans Polska sp. z o. o. [Navatrans Polska } \\
\text { Limited] }\end{array}$ & Wroclaw & 3 pushers, 8 pushed barges \\
\hline $\begin{array}{l}\text { Przedsiębiorstwo Transportu Śródlądowego } \\
\text { Dommil Czeslaw Szarek [Inland Transport } \\
\text { Company Dommil] }\end{array}$ & Kędzierzyn- Koźle & 2 pushers, 2 pushed barges \\
\hline Wodtrans s.c. [Wodtrans Partnership] & Bydgoszcz & 3 pushed barges \\
\hline Żegluga HTŚ sp. z o.o. [HTŚ Shipping Limited] & Gdańsk & 2 pushers, 4 pushed barges \\
\hline Przedsiębiorstwo Comal [Comal Company] & Gdańsk & 4 tank barges, 1 pushed barge \\
\hline Wisłă-Flis & Gdãúsk & 1 motor bărgè, 1 pushed bărge \\
\hline $\begin{array}{l}\text { Przedsiębiorstwo Uslug Wodnych Marcin } \\
\text { Jurkowski [Water Services Company Marcin } \\
\text { Jurkowski] }\end{array}$ & Warszawa, Zegrze & 2 pushed barges \\
\hline Ryszard Marczewski & $\begin{array}{l}\text { Sandomierz, } \\
\text { Polaniec }\end{array}$ & 1 pushed barge, 1 barge with full deck \\
\hline $\begin{array}{l}\text { Firma Handlowo-Uslugowa Rzeka s.c. [River } \\
\text { Trade-Services Company Partnership] }\end{array}$ & Szczucin & 1 tugboat, 3 pushed barges \\
\hline Kazimierz Michalik & Cracow & 2 pushers \\
\hline $\begin{array}{l}\text { Przedsiębiorstwo Prywatne Żegluga Krakowska } \\
\text { [Cracow Shipping Private Company] }\end{array}$ & Cracow & 1 pusher, 1 barge \\
\hline
\end{tabular}

Authors' own work based on Polski Rejestr Statkow and carriers' webpages.

the transport of mass freight like pushers, tugs, pushed and motor barges have been taken into account. Motor boats and dinghies were not included on the assumption that these are not suited to the commer- cial transport of commodities. Among the 28 vessels, 15 are motor barges. Seven are stationed at the ports of Bydgoszcz, four each in Szczecin and Wroclaw. Also in the hands of private carriers are six pushers 
at the ports of Kędzierzyn-Koźle, Januszkowice, Szczecin, Płock and Warsaw. Tugs were registered at the river ports of Opatowiec and Wroclaw. Five owners possess pushed barges only.

\section{CONCLUSIONS}

Physical conditions limit the potential development of Poland's inland shipping, ensuring that its significance is much more limited than in many Western European countries. Factors exerting a negative influence include prolonged ice-cover and considerable fluctuations in water level, these combining with serious shortfalls as regards infrastructure and equipment to limit shipping to just a few months a year. Also disadvantageous (from this point of view at least) is the almost wild character of navigable rivers. A classic example here is the Vistula, along which almost no carriage of commodities takes place. Only some segments of Poland's rivers fulfil the standards for international waterways. Thus, should further steps towards the improvement of infrastructure not be taken, inland shipping will be marginalized, especially in the carriage of cargo.

As regards freight traffic, a downward trend for national carriage is to be observed. In line with this, a substantial reduction in the size of the fleet in Polish inland shipping ownership is taking place. Simultaneously, to avoid complete annihilation, Polish shipowners have considered joining forces on the domestic market (the creation of a group embracing two largest subjects-Odratrans and Bydgoszcz Shipping) as well as internationally (through the purchase of German competitor Deutsche Binnenreederei). The latter move in particular should be evaluated as very favourable-the opening up of EU markets to Polish cabotage certainly contributed to a significant change in the pattern of carriage. Nowadays, Polish shipowners are responsible for over half of the carriage internationally, principally in cabotage on German territory. Equally disadvantageous in this case is the dependence on a single
(German) market. The structure to carriage on the domestic market is not very favourable either-what is mainly involved is the shipping of unprocessed raw materials over short distances (a large share of goods are transported over distances of up to $49 \mathrm{~km}$ ). A very worrying issue is in turn the ongoing ageing of the fleet, with practically no effort made to rejuvenate it. Further maintenance of this trend may upset the position of Polish shipowners on the domestic and international markets (Diagnoza..., no date; Wojewódzka-Król 2006).

Certain changes in carriage and fleets are also observable in passenger shipping. The level of carriage has declined much less markedly than has freight shipping, indeed some increase in numbers of passengers transported has even been noted in recent years. This has been accompanied by some enlargement of the fleet, albeit mainly on the basis of elderly vessels that are probably often madeover versions of former cargo vessels. In the case of passenger carriage there is in fact a decline in international traffic. This is most probably a result of Poland's accession to the EU and of the disappearance of cruises offering access to duty free shops (mainly in the environs of Szczecin and Świnoujście). In Poland, there is thus far none of the use of navigation in public urban transport that is popular in Western Europe. For example, solutions popular in Switzerland where vessels provide for daily commuting, are not common here. However, this sort of transport has now started up, mainly in the form of the water tramways operating in such cities as Warsaw, Bydgoszcz and Gdańsk. Only in the case of the city of Świnoujście does ferry shipping play an important role. In other cases, carriers first and foremost offer cruises around cities and in naturally-attractive areas. In just a few cases, mainly on the Elbląg Canal and the Great Mazurian Lakes, are shuttle voyages organized.

At present, private inland shipping companies prevail. Some of these are family firms and are very small indeed-with just a single vessel. It is in freight carriage that 
the Odratrans group dominates, as well as in passenger traffic. In many regions, in passenger carriage in particular, there are nothing but private firms, the public sector being limited to the services of shuttle tours in urban transport (including cruises along the Elbląg Canal). In freight traffic a marginal role is played by Szczecin Shipping as a single-person Treasury company. At the same time, it is possible to observe in Poland a much greater concentration of the inland shipping cargo fleet in single hands than is to be noted in the countries of the older UE.

By and large, inland shipping in Poland is among the most deregulated modes of transport, in which private property is the absolute dominant. It should be recalled that, due to the poor state of the waterways in Poland, most freight carriage takes place in the area between the Odra and the Rhine. The neglect of waterways by the authorities in Poland may ultimately lead to a situation in which inland shipping becomes nothing more than a tourist attraction and supplier of cheap transport services to more developed economies of Western Europe with all the attendant detrimental effects to the national economy that that would entail.

\section{REFERENCES}

Bąkowski, W. (1995), Rola malych, średnich i dużych firm w transporcie [The role of small, medium-sized and large firms in transport], in: Materiaty międzynarodowej konferencji 'Wspólna Europa: szanse i zagrożenia dla transportu', Warszawa, SGH, pp. 367-379.

Bujak, A. (2008), Żegluga śródlądowa w ujęciu pragmatycznym [Inland shipping conceptualised pragmatically], Przeglad Komunikacyjny, 9: $16-19$.

Czermańska, R., Czermański, E., Łuczak, B. and Kowalczyk, U. (2003), Stan techniczno-organizacyjny portów sródladowych w Polsce [Technical-organizational state of inland ports in Poland], Gdańsk: Instytut Morski, mimeo.

Diagnoza stanu istniejacego rozwoju żeglugi śródladowej $w$ Polsce [Diagnosis of the condition of inland shipping development in Poland] (no date), Warszawa, Ministerstwo Infrastruktury, Departament Transportu Morskiego i Żeglugi Śródlądowej, mimeo.

Europe develops inland shipping (2001), Lloyd's Shipping Economist, 8 [after:] Paprocki and J. Pieriegud (2004) Perspektywy rozwoju polskiej żeglugi śródlądowej w rozszerzonej Unii Europejskiej [Prospects for the development of Polish inland shipping in the enlarged European Union], Problemy Ekonomiki Transportu, 1: 57-69.

Kulczyk, J. and Winter, J. (2003), Sródladowy transport wodny [Inland water transport], Wroclaw, Oficyna Wydawnicza Politechniki Wrocławskiej.

Kwiatkowska, E. (1992), Przemiany w żegludze śódlądowej [Changes in inland shipping], Przeglad Komunikacyjny, 7-8: 10-13.

Lepek, H. (2009), Rola żeglugi śródlądowej w europejskim systemie transportowym [Role of inland shipping in European transport system] in Babiński, J. (ed.), Rewitalizacja drogi wodnej Wista-Odra szansa dla gospodarki regionu, Bydgoszcz, Urząd Marszałkowski Województwa Kujawsko-Pomorskiego, Instytut Geografii UKW, pp. 13-30.

Milkowski, M. (1997), Dylematy i szanse polskiej żeglugi rzecznej [Dilemmas and chances of Polish river shipping], Przeglad Komunikacyjny, 2: 10-17.

Odratrans-prospekt emisyiny [Odratrans-prospectus] (2005), Wroclaw, Odratrans SA.

Paprocki, W. and Pieriegud, J. (2004), Perspektywy rozwoju polskiej żeglugi śródlądowej w rozszerzonej Unii Europejskiej [Prospects for the development Polish inland shipping in enlarged European Union], Problemy Ekonomiki Transportu, 32, 1:57-69.

Polski Rejestr Statków [Polish Registry of Ships] (2009). Dane ze świadectwa klasy statków śródlądowych. Available at: <www.prs.pl> (accesssed 5 February 2010).

Rydzkowski, W. and Rolbiecki, R. (1993), Przeksztalcenia własnościowe i strukturalne w transporcie wodnym śródlądowym [Ownership and structural transformation in inland water transport], Przeglad Komunikacyjny, 12: 14-16. 
Sibilski, W. (2003) Grupa kapitałowa Izo-ErgOdratrans-Żegluga Bydgoska: przegrupowanie barek i pchaczy [Capital group Izo-ErgOdratrans-Zegluga Bydgoska: reorganization of barges and pushers]. Available at: <www. gazeta.pl $>$ (accessed 1 February 2010).

Taylor, Z. and Ciechański, A. (2006), Deregulation in Polish rail transport, Transport Reviews, 26, 3: 305-324.

Taylor, Z. and Ciechański, A. (2008), What happened to the national road carrier in a postcommunist country? The case of Poland's State Road Transport, Transport Reviews, 28, 5: 619-640.

Taylor, Z. and Ciechański, A. (2010a), Organizational and ownership transformation in Poland's urban transport companies, Transport Reviews, 30, 4: 407-434.

Taylor, Z. and Ciechański, A. (2010b), Przekształcenia organizacyjno-własnościowe polskich przedsiębiorstw żeglugi śródlądowej i przybrzeżnej po $1990 \mathrm{r}$. [Organizational and ownership transformation in Poland's inland and coastal shipping companies after 1990], Przeglad Geograficzny, 82, 2: 191-220.

Ustawa z dnia 7 marca 1950 r. o żegludze i spławie na śródlądowych drogach wodnych [The Act on Shipping and Floating on Inland Water Routes of 7 March 1950] (1950), Dziennik Ustaw PRL, 10, item 108.

Ustawa z dnia 24 października 1974 r. Prawo wodne [The Water Law Act of 24 October 1974] (1974), Dziennik Ustaw PRL, 38, item 230.

Ustawa z dnia 23 grudnia 1988 r. o dzialalności gospodarczej [The Act on Economic Activity of 23 December 1988] (1988), Dziennik Ustaw PRL, 41, item 324.

Ustawa $\mathrm{z}$ dnia 21 grudnia 2000 t. o żegludze śródlądowej [The Act on Inland Shipping of 21 December 2000] (2001a), Dziennik Ustaw RP, 5 , item 43.

Ustawa z dnia 18 lipca 2001 r. Prawo wodne [The Water Law Act of 18 July 2001] (2001b), Dziennik Ustaw RP, 115, item 1229.

Wojewódzka-Król, K. (2006) Kierunki rozwoju żeglugi śródlądowej w Polsce: założenia do strategii na lata 2007-2013 [Directions to the development of inland shipping in Poland: Assumptions to the strategy for 2007-2013].
Available at: <www.zegluga.wroclaw.pl $>$ (accessed 15 February 2010).

Wojewódzka-Król, K., Rydzkowski, W. and Rolbiecki, R. (2000), Polskie przedsiębiorstwa żeglugi śródlądowej przez przyjęciem RP do Unii Europejskiej [Polish companies in inland shipping before the accession of Poland to the UE], Przeglad Komunikacyiny, 10: 19-22.

$<$ www.odratrans.com.pl> Homepage of the Odratrans group (accessed 30 January 2010). <www.zegluga.com.pl> Homepage of ElblagOstróda Shipping (accessed 30 January 2010). $<w w w . z e g l u g a . p l>$ Homepage of Gdańsk Shipping (accessed16 March 2010).

Paper first received: June 2011

In final form: August 2011 